\title{
ANALYSIS OF THE DIMENSIONS OF SERVICE QUALITY IN LINER MARINE TRANSPORTATION BY STRUCTURAL EQUATION MODELING
}

\author{
Ayşe TAŞ ${ }^{1}$, Murat YORULMAZ ${ }^{2}$
}

\begin{abstract}
The purpose of this study is to identify the dimensions that constitute the quality of the services offered in the liner maritime transport through the measurement model developed based on the ROPMIS model by Thai (2008), and to examine the reliability and validity of these dimensions with structural equation modelling. The data were obtained from 316 employees working at 52 businesses through questionnaire and analysed through SPSS v22 and AMOS v22 Statistics. The findings indicate that the dimensions of resources, outcomes, process, management, image, and social responsibility in the measurement model are sufficient to explain the quality of service and that the service quality measurement model can be used both as a first-level multifactorial model and a second-level model. Further, the analyses for convergent and discriminant validity performed based on the data from the confirmatory factor analysis show that the measurement model is structurally valid and reliable.
\end{abstract}

Key words: Liner Marine Transportation, Maritime Management, Service Quality Dimensions.

JEL Classification: M10, M16, M30

\section{DÜZENLİ HAT DENIZ TAŞIMACILIĞINDA HİZMET KALITESİNI OLUŞTURAN BOYUTLARIN YAPISAL EŞITLIKK MODELLEMESIYYL ANALIZi}

\author{
Öz
}

Bu çalışmanın temel amacı, layner deniz taşımacılığında verilen hizmetlerin kalitesini oluşturan boyutların Thai'nin (2008) ROPMIS modeli esas alınarak hazırlanan ölçüm modeline göre belirlenmesi ve boyutların güvenilirliklerinin ve geçerliliklerinin yapısal eşitlik modellemesi ile incelenmesidir. Bu amaca yönelik olarak da Türkiye'de faaliyet gösteren 52 forvarder işletmesinin 316 çalışanından anket tekniği ile toplanan veriler SPSS v22 ve AMOS v22 paket programları kullanılarak analiz edilmiştir. Analiz bulguları, ölçüm modelinde yer alan kaynaklar, çıktı, süreç, yönetim, imaj ve sosyal sorumluluk boyutlarının, layner deniz taşımacılığının hizmet kalitesini açıklamakta yeterli olduğu ve hizmet kalitesi ölçüm modelinin hem birinci düzey çok faktörlü hem de ikinci düzey olarak kullanılabileceğini göstermektedir. Ayrıca doğrulayıcı faktör analizi ile elde edilen veriler kullanılarak yapılan benzeşme ve ayrışma geçerliliği analizleri sonucunda, ölçüm modelinin yapısal olarak geçerli ve güvenilir olduğu tespit edilmiştir.

Anahtar Kelimeler: Layner Deniz Taşımacılığg, Deniz İşletmeciliği, Hizmet Kalitesi Boyutları.

JEL Sinıflaması: M10, M16, M30

\footnotetext{
${ }^{1}$ Lect. Dr., Kocaeli University, Maritime Faculty, Department of Maritime Business Administration, ayse.tas@kocaeli.edu.tr , ORCID: 0000-0002-2457-7723.

${ }^{2}$ Asst. Prof. Dr, Kocaeli University, Maritime Faculty, Department of Maritime Business Administration, murat.yorulmaz@kocaeli.edu.tr, ORCID: 0000-0002-5736-9146.
} 


\section{Introduction}

Maritime transport, when its services are provided, is a fundamental factor for the development of the national economy of any maritime country. In terms of the continuity of service, maritime transport is categorized into two main sectors as liner and tramp transport (Haralambides, 2007); in particular, liner transport based on a tariff-based system has recently become the fastest growing transport type. As of 2018, the share of container transportation in liner transport, which includes both ro-ro transportation and container transportation, has been $16 \%$ equal to 1.87 billion tons (IMEAK, 2019). "In 2018, the world's container fleet will exceed the increase in demand by only $6-7 \%$ by increasing by $9.2 \%$ and enhance surplus." This indicates that supply will exceed demand in the next years and competition between liner container lines in the maritime transport sector will become increasingly fierce (Tuan et al., 2018).

Due to the fierce competition in the liner transport market, the low profit margins because of the overcapacity problem, and the content of the services offered by the competitors being gradually similar, a liner transport company need to differentiate its services from its competitors. However, as liner transportation is based on standardization, differentiation in the market is quite a problem (Balci et al., 2018). Differentiation can be achieved by any feature valued by customers. This differentiation is that service features, which are of great important for customers, have a distinctive nature. And this depends on delivering quality services that create differentiation. A differentiated service leads to an increase in a company's revenues, its market share and the likelihood of repurchases by customers (Dennet't et al., 2000).

Quality management in liner maritime transport entails the continuous improvement and development of quality factors in order to increase the competitiveness in the market (Samija et al., 2015). These quality factors are the dimensions that constitute service quality. It is thus necessary to identify these dimensions. Because it is essential that dimensions of service quality are known and service quality is measurable so that the customer using these services (users) can perceive quality.

Studies on the quality dimensions and quality measurement of the liner maritime transport services are limited, due to the large number of actors in the maritime transport chain and the uniqueness and complexity of this transport type (Samija et al., 2015). While there are numerous studies on service quality in other sectors, very few research directly addresses the dimensions and criteria (determinants) of quality in liner maritime services. Such dimensions and criteria are discussed in studies emphasizing mode or carrier selection criteria (Ho et al. 2017; Fanam \& Ackerly 2019, Kannan, et al. 2011; Ding \& Tsai, 2012). On the other hand, the analysis and discussion of the selection variables based on groups of factors allows for identifying the service- and performance-related attributes that are considered to be within the scope of dimensions of service quality (Thai, 2008).

There are also studies in the literature, conducted with the service quality measurement model SERVQUAL, which directly measure service quality in maritime transport identify its dimensions/factors (Durvasula et al., 1999; Chen et al., 2009; Kang \& Kim 2009; Tuna 2001; Yüksel and Önaçan, 2018). 
This model is a 5-dimensional (concrete elements, reliability, competence, trust, empathy) model that is most widely used for the evaluation of service quality, and the SERVQUAL scale is favoured as it offers flexibility for different sizes and factors of various service types (Seth et al., 2005). This scale has also some weaknesses and has been thus criticized by researchers (Erenkol, 2005). For this reason, some researchers stated in their studies with the SERVQUAL scale that the validity of this scale was not established (Chen, 2009; Durvasula, 1999; Kang \& Kim 2009), whilst others confirmed the validity of this scale (Tuna, 2001).

Chen et al. (2009) drew on the 5-dimensional SERVQUAL scale with explanatory factors for 22 service features to measure the service quality in the container transport industry in Taiwan. Consequently, the validity of SERVQUAL was denied. The potential reason for this was reported the lack of some critical service features of the sector in the scale. In other words, the scale was perhaps denied because of the fact that it failed to address to a wide range of industry needs and requirements (Kang, \& Kim 2009). This present study presented additional evidence to the controversy over the validity of this scale. The authors claimed that the SERVQUAL scale was developed from the perspective of end consumers. They noted that this perspective does not fit the maritime transport sector, which is a predominantly business-to-business (B2B) industry. All things considered, service quality management is more complex and attributed to a larger group of suppliers (customers) interacting with a service provider on a personal or functional level (Chen et al., 2009).

Researchers assessing the SERVQUAL model argued that the criticisms on the dimensions of the model were that the five dimensions of the SERVQUAL model were insufficient to generalize for all service sectors and cannot be applid universally, raising questions about its reliability as a scale (Durvasula et al., 1999). The reason why the five dimensions of the SERVQUAL model for service quality cannot be applied to service industry is perhaps that service businesses and their sub-sectors have unique (characteristics) structures and that the business strategies, cultures, customer portfolio, region, size etc. of these structures differ depending on various factors. Applying a standard scale or model to all service sectors, regardless of the differences they have, may lead to erroneous results or evaluations. As such, some models that will comply with the unique structure of the service sector are recommended.

One of them is the ROPMIS model proposed by Thai (2008) considering the unique structure of maritime transport. Thai criticized the content of the SERVQUAL scale and claimed that the five dimensions of this scale were insufficient to generalize to maritime firms and cannot be universally accepted.

The researcher further argued that the SERVQUAL model is geared towards the consumer market whilst the quality models of maritime transport services need to be geared towards B2B markets. Since the purchasing behavior of the end consumers and of B2B businesses are different, Thai stated that the dimensions and variables in the measurement model of the service quality of maritime transport businesses, which are one of the businesses involved in B2B markets, should reflect the structure and differences of the sector which they are in. One of the most comprehensive studies in this regard has previously attempted to comprehensively review all relevant literature and recommended and approved ROPMIS, which is an overall service quality model to define service quality for the entire maritime industry (Thai, 2008, Yuen et al., 2015). 
Thai (2008) stated that the dimensions of management, social responsibility and image are lacking in maritime transport due to its unique features. He developed the ROPMIS model, which is a general conceptual model of maritime transport with a total of 6 dimensions (resources, management, process, results, social responsibility and image) and 24 factors that include these dimensions. The superiority of this model is that it is the result of the theoretical synthesis of many other models, primarily the SERVQUAL scale (Thai, 2008; Yuen et al., 2015; Thai, 2016; Yeo et al., 2015; Tuan, 2018). Compared to SERVQUAL, the ROPMIS model is more suitable for the maritime industry as it incorporates the critical elements of image and social responsibility (Thai, 2016).

The dimensions and variables of the service quality model in the mentioned study suggested that they can be generalized to maritime transport businesses and its variables can be revised based on the dimensions of other service organizations and used according to the characteristics of the service. In other words, although it is expected that the model is applicable to maritime transport services in general, the author argued that its factors can be easily revised for certain sub-sectors such as ports. For this reason, there are few studies in literature that revised the factors of the ROPMIS model (Yeo et al., 2015; Thai, 2016).

Thai (2008) used a sample of port operators, maritime transport companies, and forwarders/logistics service providers in Vietnam and administered a questionnaire consisting of 24 explanatory criteria under 6 dimensions in the ROPMIS service quality model to the companies in the sample. Thai analysed a total of 120 data sets through SPSS v13 statistics and thematic analysis technique and concluded based on the findings of the analysis that the ROPMIS measurement model for service quality is reliable and valid. To identify the service quality dimensions of the liner maritime transport in Turkey, an experimental study benefited from the six dimensions and factors of the ROMPIS model. The findings of an experimental study without using an academically-validated scale would not be considered reliable. However, there is a growing debate that the interpretation of service quality differs across industries, customer groups and countries/cultures (Eleren \& K1lıç, 2007). As the interpretation and perception of service quality dimensions may differently affect customers, the results are likely to be valid only for Vietnam.

For these reasons, the purpose of this study is to identify the dimensions that constitute the quality of the services offered in the liner maritime transport through the measurement model developed based on the ROPMIS model by Thai (2008), and to examine the reliability and validity of these dimensions with structural equation modeling. To that end, a 31-item survey was administered to 316 employees in forwarder businesses, which are one of the two main customer groups as the shipper of the liner transport companies operating in Turkey. The obtained data were analysed through SPSS v22 and AMOS v22 software.

The 24 criteria in the 6 dimensions of the original ROPMIS service quality model developed by Thai were transformed into 31 questions considering the unique features of liner transport. The criteria in some dimensions, which were considered significant, were elaborated and increased (for example, the competitive freight application criterion under the dimension of outcomes was elaborated into reduction in the local costs of liner companies and flexibility in container free times; so, the number of criteria for this dimension increased.)

The results of the analysis indicate that the model can be used as a reliable tool to measure service quality in liner maritime transport. 
The findings of this study can also offer meaningful inferences for managers in liner transport companies. The validated ROPMIS model in this study helps company managers understand which dimensions and aspects of service quality in liner maritime transport are prioritized and taken into account by customers. Understanding which factors can make a difference in order to compete with other companies will guide company managers while delivering their services. Based on this understanding, company managers can develop a standard service quality scale to measure customer satisfaction. In the long term, the use of such a standard measurement tool will facilitate the comparison between services of other liner businesses in terms of service quality performances, and thus, liner transportation will be able to apply the necessary solutions to increase the service quality.

\section{Theoretical Framework}

\subsection{Service Quality}

Service quality refers to an overview of the service delivery system and can also be defined as the customer's overall impression of the relative superiority or weakness of the company's performance (Zin, 2014: 3). One of the key elements that distinguish a service business from its competitors is producing and providing a better quality service than its competitors (Durvasula et al., 1999). Customers always compare the service they receive with the service they expect. Then, if customers find that the service they receive is above their expectations, they are more satisfied and continue to receive that service. Many service organizations outperform its competitors with the strategy of producing and offering distinct and desired quality services and maintain their profitability, thus gaining competitive advantage (Seth, 2005). It is challenging to define and measure services due to their characteristics such as abstraction, heterogeneity, synchronicity, and durability (Parasuraman et al., 1988).

Studies that were performed to measure service quality generally focus on conceptual models containing the definition and dimensions of service quality or on the measurement of service quality. In this regard, many researchers attempted to measure service quality using these two perspectives and drawing on different methods. There are many theoretical models for service quality in the literature (Seth et al., 2005). The model considered as the model of service quality in the literature is the technical and functional quality model of Grönroos (1984), which emphasizes that the expected service must match with the perceived service for a business to achieve customer satisfaction. The resulting perceived service quality is influenced by three factors: image, technical quality and functional quality (Seth, et al., 2005). These three factors are the dimensions of quality in the model that are used to determine the quality of the service provided and are taken into account by customers (Grönroos, 1984).

The SERVQUAL model was developed following this first model and the SERVQUAL model is a technique intended to measure the level of service quality of a business through the difference analysis method based on the needs of customers regarding service quality. As the most preferred scale in the above mentioned studies, the SERVQUAL scale is a research tool with 22 criteria that can measure the quality of services offered by all kinds of service businesses based on 5 dimensions, which are concrete features, reliability, enthusiasm, trust and empathy (Parasuraman et al.,1988). The fact that the SERVQUAL model is the most preferred scale has caused many positive and negative criticisms. 
While some of the studies attempted to prove the validity of the SERVQUAL scale in different types of service sectors, others argued that SERVQUAL cannot be applied to every service sector (Chen et al., 2009; Durvasula et al., 1999). They mostly criticized the scale due to the difference score between "Perception - Expectation", the dimensions, applicability, and lack of validity of the model (Erenkol, 2005). Cronin and Taylor, which argued that the SERVQUAL model is not sufficient to measure the service quality, developed the SERVPERF based on performance. The authors put forth that service quality is only a function of perceived performance. Also, the authors claimed that the SERVPERF model consists of only one dimension rather than five dimensions as in the SERVQUAL model (Bülbül \& Demirer, 2008). These are the basic quality models, and different quality models have been derived from these models. There are Service Quality Model for Banking Sector, Information Technology-based (IT) model, E-Service Quality Model, Internet Banking Model, Retailers Service Quality and Perceived Value Model. Besides, quality models for special services according to the originality of the service are available, such as LODGSERV for accommodation establishments, DINESERV for restaurant services, ECOSERV for the quality expectations of ecotourists, HISTOQUAL for historical houses and museums (Seth et al., 2005; Eleren, 2009). These models are different due to service design, customer expectations, customer needs and expectations, determination of the ideal and ideal service quality, and the change in service quality according to cultural differences (Seth et al., 2005; İkiz, 2010).

As with other service sectors, maritime transport services have their own unique quality models for quality management, such as the ROPMIS model proposed by Thai (2008).

The quality management process in maritime transport involves activities that are based on wellstudied current and future needs of users who seek the design and implementation of everything necessary and that focus on providing market-based and market-appropriate services. The common goal of all these activities is to achieve optimal profitability, to secure the appropriate position in the transport market and to ensure sufficient competitiveness. This entails the continuous improvement and development of quality factors in order to increase the competitiveness of quality management in the market during the transportation process (Samija et al., 2015). Service quality in maritime transport has multiple dimensions on the aspects of the service assessed by customers. Thus, it is essential to identify these dimensions.

\subsection{Dimensions of Liner Maritime Transport on Service Quality}

Maritime transport is carried out in two main ways as scheduled (liner) transportation and nonscheduled (tramp) transportation; the nature and features of these transportations are different from each other. Tramp transport is a form of transport between any two ports with a load and without a specific schedule and route. On the other hand, liner transportation is a form of transportation that uses regular routes on fixed schedules. In liner transportation, ships operate along pre-determined ports of departure and arrival as well as transfer ports on predetermined dates and perform loading and unloading operations; liner ships are mostly container ships. Container transportation is one of the most favored type of transformation in liner transportation (Karsten, 2015: 11). In this type of transformation, which involves fierce competition, it is prerequisite to offer high-quality services to achieve competitive advantage. High-quality services are of importance for a carrier to differentiate itself from its competitors in order to gain competitive advantage. 
For liner transport companies, "factors such as timely arrival of the ship, freight pricing, efficient cargo tracking, trip frequency, safety of the transportation, rapid response to customer needs, full compliance with itineraries, trip frequency to port of arrival, reliability of booking services are alternatives for differentiation in container transportation." (Durvasula et al., 2002). All these factors are criteria that are included in as well as explain and define the dimensions of service quality. For that reason, it is of key importance to understand and manage service quality in liner transportation in order to identify which dimensions of service quality to address.

The dimensions of service quality must be clearly outlined in order for customers or users to recognize quality. Defining service quality and its dimensions is significant for revealing the strengths or weaknesses of the businesses and also for the effective use of organizational resources (Chen et al., 2009). Research on the dimensions and determinants of service quality in businesses offering liner transport is rather limited as well.

However, the dimensions and factors of service quality in businesses offering liner transport have been discussed in studies in the literature on services, transport modes, carrier selection criteria, logistics service quality and SERVQUAL service quality, ROPMIS service quality model.

As carrier selection criteria are related to service performances determined through various analyses in a number of studies, it is considered that these criteria are among the dimensions of service quality (Thai, 2008). For the purpose of evaluating the decision-making process related to carrier selection in linear transportation Fanam \& Ackerly (2019) identified the following five dimensions regarding the selection of liner transportation lines: "service fee, itinerary \& freight network, door-to-door transport, corporate social responsibility" They concluded that the most important criteria explaining these dimensions are "the lowest possible freight rate, flexibility of freight rate, domestic and international service network, schedule reliability (ontime arrival and departure), schedule frequency, transit timeframe, perceived reputation of carrier, problem-solving capability"

In their research on carrier selection of forwarder businesses related to liner transport, Ho et al. (2017) listed the following dimensions in the selection of liner transport lines: shippers' needs, shippers' costs, shippers' communication and shippers' convenience. They further determined that the most important criteria explaining these dimensions are "transport reliability, integrated logistics, flexible freight tariffs, timely delivery, direct access, sailing frequency and custom clearance efficiency" In other words, these are the dimensions and criteria that affect service quality in liner transport.

Zin et al. (2014) aimed to grasp an understanding of logistic service quality in maritime transport, to identify the dimensions that explain logistic service quality in maritime transport and to develop and test a scale with descriptive criteria that best represent these dimensions, to explore the relationships between service quality, customer satisfaction and loyalty; then, they identified seven dimensions regarding service quality in maritime transport: "professional skills for logistics, resources, process, outcomes, service cost, image and environmental responsibility" They stated that the most critical criteria explaining these dimensions are: "physical infrastructure, expert human resources, financial stability, competitive pricing of services, efficient delivery of door-to-door transport services, reliability of cargo booking services, environmentally safe operations, good reputation in the maritime market, etc.", 
Tuan et al. (2018), who attempted to explore the factors affecting customer satisfaction (from export firms) while using liner transportation services, drew on the ROPMIS model. The researchers reported that the quality dimensions of their research model consist of five dimensions: "resources, outcome, process, management and brand"

Thai (2008) sought to enhance information available on the concept of service quality in maritime transport and to identify the dimensions that explain service quality in maritime transport and to develop and test a model with descriptive criteria that best represent these dimensions.

The researcher ascertained the following six dimensions: "resources, outcomes, process, management, images and social responsibility" The dimensions of this conceptual model of maritime transport service, which is also called ROPMIS in the literature, consist of 24 descriptive criteria.

The "resources" dimension of the ROPMIS model by Thai (2008) includes five criteria, which are "equipment and facilities availability, equipment and facilities condition, financial stability, shipment tracing capability, physical infrastructure" The "outcomes" dimension consists of six criteria, which are "speed of service performance, reliability of service performance, providing service in a consistent manner, shipment safety and security, reliability of documentation, competitive price of service" The "process" dimension includes four criteria, which are "staff's attitude and behaviour in meeting customer requirements, quick response to customers' inquiries, knowledge of customers' needs and requirements, application of IT and EDI in customer service" The "management" dimension consists of six criteria, which are "application of IT and EDI in operations, efficiency in operations and management, knowledge and skills of management and operators, understanding customers' needs and requirements, feedback from customers, continuous improvement of customer-oriented operation processes" As for the "image" dimension, only one criterion has been identified: "company's reputation for reliability in the market" The "social responsibility" dimension has two criteria, which are "socially responsible behaviour and concerns for human safety, environmentally safe operations"

The 24 criteria in the 6 dimensions of the original ROPMIS service quality model developed by Thai were transformed into 31 questions considering the unique features of liner transport. For example, the competitive freight application criterion under the dimension of outcomes was elaborated into reduction in the local costs of liner companies and flexibility in container free times; so, the number of criteria for this dimension increased. Likewise, the criteria in the dimensions of image and social responsibility were also increased as they were considered significant. Further, some criteria, including expert human resources, accurate and efficient cargo booking services, which were notable regarding the operations related to maritime transport in the literature review on service quality in liner transport, were included as well. Appendix 1 presents the survey questions on the dimensions of the ROPMIS model for service quality in liner transport and the criteria that constitute these dimensions. 


\section{Research Method}

\subsection{Research Purpose and Significance}

The research question is, does the ROPMIS model developed by Thai (2008) used to measure maritime transport service quality have structural validity and reliability in Turkish usage?. The primary purpose of this study is to identify the dimensions that constitute the quality of the services offered in the liner maritime transport through the ROPMIS model by Thai (2008), and to examine the reliability and validity of these dimensions with structural equation modelling. Bringing the ROPMIS model, whose dimensions, structural validity, and reliability were revealed in this study, to the Turkish maritime literature will fill an important gap.

\subsection{Research Population and Sample}

The research population consists of the forwarder businesses that operate in Turkey and use liner maritime transport services. Simple random sampling technique was used in the selection of the sample, and the data obtained from the surveys, which were sent back to the forwarder businesses registered with the IMEAK, constitute the data of the research. The data were obtained from 316 employees working at 52 businesses through questionnaire between November, 2019 and March, 2020, and analysed through SPSS v22 and AMOS v22 Statistics. According to Kline (2014), it is important that the sample size should be at least five or ten times more than the variables observed. Therefore, it can be claimed that a sample of 316 people is sufficient for a total of 31 items in the scale of service quality used in this study.

\subsection{Measurement Tool}

The questionnaire used in this study to collect the data consists of two sections. The first section presents questions to ascertain the demographic characteristics of employees in forwarder businesses. The second section presents the questionnaire with 31 items and 6 dimensions of resources (RES), outcomes (OUT), process (PRO), management (MAN), image (IMA) and social responsibility (SOR) intended to measure service quality in maritime businesses that carry out liner maritime transport; Appendix 1 shows the details of the questionnaire (dimensions, criteria and resources). All items in the scale were rated on the 5-point Likert-type scale. The participants were asked to mark the options suitable for themselves. The scale ranged from $1=$ totally disagree to $5=$ totally agree.

\section{Findings}

\subsection{Demographic characteristics of the participants}

$52.8 \%$ of the participants stated that they work in the head office of the businesses whereas $47.2 \%$ reported that they work in a branch of the businesses. The businesses where the participants work offer various services other than forwarding services (i.e. organizing transportation), such as shipping agencies, road transportation, air cargo transportation, project transformation as well as maritime transportation services.

$33.1 \%, 19.7 \%, 15.4 \%, 6.8 \%$ and $5.6 \%$ of the participants reported to have employees between $11-20,1-10,21-30,41-50$ and $31-40$, respectively. $19.4 \%$ of the participants reported to have 51 or more employees. Further, $69.2 \%$ reported that they work in non-management positions whilst $30.8 \%$ work in management positions. 
$25.8 \%, 25.4 \%, 18.4 \%, 17.7 \%$ and $4 \%$ of the participants reported that they have been working in their current businesses for 11-15 years, 6-10 years, 25 years or more, 1-5 years and 21-25 years, respectively.

Besides, $37.5 \%, 36.5 \%, 18.1 \%, 5.4 \%$ and $2.5 \%$ reported to have experience in forwarding between 5-9 years, 1-4 years, 9-14 years, 5-9 years and 20 years or more, respectively.

\subsection{Validity and Reliability Analyses}

Structural equation modeling (SEM), which is preferred to determine structural validity and reliability, is a powerful method especially used in validation of complex models and path analysis. It is a method that has been used frequently in recent years because the relations between the variables are handled as a whole in the analyzes made with SEM and can be processed in the errors that may arise from the measurement (Hair et al., 2014). Confirmatory factor analysis (CFA) was conducted to determine the structural validity of and to identify the factor structure of the measurement model used in the study. Table 1 presents the standardized factor values, $t$ values, average variance values (AVE), combined reliability (CR) coefficients and Cronbach's Alpha (CA) values of the variables observed in the findings of the measurement model from the CFA. Table 2 shows the maximum shared variance (MSV) values and average shared square variance (ASV) values. The standardized factor loads of the variables observed in Table 1 and the AVE values were greater than 0.50 and statistically significant $(p<0.001)$; besides, CR values were greater than both 0.70 and AVE values, and CR values were higher than 0.70 , which is a threshold value. This, thus, confirmed that the dimensions of the measurement tool were convergently valid.

Table 1. Validity, Combined Reliability, Cronbach's Alpha, Skewness and Kurtosis Coefficients.

\begin{tabular}{|c|c|c|c|c|c|c|c|c|c|}
\hline & Item & Std. $\beta$ & SE & t-value & Skew. & Kurt. & AVE & CR & CA \\
\hline \multirow{5}{*}{$\begin{array}{l}\mathbf{R} \\
\mathbf{E} \\
\mathbf{S}\end{array}$} & RES1 & 0.588 & & - & -0.501 & -0.404 & \multirow[t]{5}{*}{0.609} & \multirow[t]{5}{*}{0.885} & \multirow[t]{5}{*}{0.874} \\
\hline & RES2 & 0.818 & 0.114 & $11.246^{* * * *}$ & -1.172 & 1.118 & & & \\
\hline & RES3 & 0.876 & 0.105 & $11.724^{* * * *}$ & -1.515 & 2.932 & & & \\
\hline & RES4 & 0.787 & 0.102 & $10.973^{* * * *}$ & -1.398 & 2.495 & & & \\
\hline & RES5 & 0.802 & 0.107 & $11.165^{* * * *}$ & -1.404 & 2.536 & & & \\
\hline \multirow{8}{*}{$\begin{array}{l}\mathbf{O} \\
\mathbf{U} \\
\mathbf{T}\end{array}$} & OUT & 0.803 & - & - & -1.317 & 1.957 & \multirow[t]{8}{*}{0.601} & \multirow[t]{8}{*}{0.923} & \multirow[t]{8}{*}{0.923} \\
\hline & OUT & 0.811 & 0.064 & $16.554^{* * * *}$ & -1.240 & 1.419 & & & \\
\hline & OUT & 0.828 & 0.053 & $17.045^{* * *}$ & -1.558 & 2.974 & & & \\
\hline & OUT & 0.774 & 0.060 & $15.520^{* * * *}$ & -1.442 & 2.781 & & & \\
\hline & OUT & 0.834 & 0.059 & $17.216^{* * * *}$ & -1.378 & 2.604 & & & \\
\hline & OUT & 0.781 & 0.058 & $15.728^{* * * *}$ & -9.307 & 2.497 & & & \\
\hline & OUT & 0.708 & 0.074 & $13.803^{* * * *}$ & -0.997 & 0.489 & & & \\
\hline & OUT & 0.646 & 0.072 & $12.312^{* * * *}$ & 1.050 & 0.779 & & & \\
\hline \multirow{6}{*}{$\begin{array}{l}\mathbf{P} \\
\mathbf{R} \\
\mathbf{O}\end{array}$} & PRO1 & 0.870 & - & - & -1.338 & 1.653 & \multirow[t]{6}{*}{0.747} & \multirow[t]{6}{*}{0.947} & \multirow[t]{6}{*}{0.947} \\
\hline & PRO2 & 0.860 & 0.047 & $21.058^{* * * *}$ & 1.346 & 1.573 & & & \\
\hline & PRO3 & 0.837 & 0.046 & $20.113^{* * *}$ & -1.359 & 1.990 & & & \\
\hline & PRO4 & 0.898 & 0.044 & $23.191^{* * *}$ & -1.313 & 1.586 & & & \\
\hline & PRO5 & 0.879 & 0.043 & $21.993^{* * * *}$ & -1.312 & 1.849 & & & \\
\hline & PRO6 & 0.841 & 0.044 & $20.108^{* * * *}$ & -1.495 & 2.683 & & & \\
\hline \multirow{4}{*}{$\begin{array}{l}\mathbf{M} \\
\mathbf{A} \\
\mathbf{N}\end{array}$} & MAN & 0.899 & - & - & -1.602 & 2.982 & \multirow[t]{4}{*}{0.681} & \multirow[t]{4}{*}{0.913} & \multirow[t]{4}{*}{0.899} \\
\hline & MAN & 0.866 & 0.040 & $22.662^{* * * *}$ & -1.433 & 3.007 & & & \\
\hline & MAN & 0.861 & 0.041 & $22.364^{* * * *}$ & -9.451 & 2.359 & & & \\
\hline & MAN & 0.576 & 0.067 & 11.834 & -2.728 & -0.774 & & & \\
\hline
\end{tabular}




\begin{tabular}{|c|c|c|c|c|c|c|c|c|c|}
\hline & MAN & 0.880 & 0.041 & $23.763^{* * *}$ & -1.445 & 2.697 & & & \\
\hline \multirow{3}{*}{$\begin{array}{l}\mathbf{I} \\
\mathbf{M} \\
\mathbf{A}\end{array}$} & IMA1 & 0.808 & - & - & -1.544 & 3.006 & \multirow[t]{3}{*}{0.567} & \multirow[t]{3}{*}{0.787} & \multirow[t]{3}{*}{0.722} \\
\hline & IMA2 & 0.478 & 0.092 & $8.796^{* * * *}$ & -0.018 & -1.125 & & & \\
\hline & IMA3 & 0.905 & 0.057 & $19.047^{* * *}$ & -1.254 & 2.182 & & & \\
\hline \multirow{4}{*}{$\begin{array}{l}\mathbf{S} \\
\mathbf{O} \\
\mathbf{R}\end{array}$} & SOR1 & 0.902 & - & - & -1.270 & 2.025 & \multirow[t]{4}{*}{0.779} & \multirow[t]{4}{*}{0.934} & \multirow[t]{4}{*}{0.932} \\
\hline & SOR2 & 0.905 & 0.038 & $25.099^{* * *}$ & -1.481 & 2.960 & & & \\
\hline & SOR3 & 0.863 & 0.041 & $22.441^{* * *}$ & -1.200 & 1.930 & & & \\
\hline & SOR4 & 0.859 & 0.041 & $22.466^{\text {**** }}$ & -1.303 & 2.363 & & & \\
\hline
\end{tabular}

Moreover, as seen in Table 2, MSV and ASV values were lower than AVE values, and the square root values of AVE were higher than the Pearson correlation coefficients, which were smaller than 0.85 . These findings confirmed that the dimensions of the measurement tool were discriminantly valid (Fornell \& Larcker 1981; Kline, 2005; Hair et al., 2014).

Both CR and Cronbach's Alpha (CA) coefficients of the measurement model, which was structurally considered a valid measurement tool with confirmed convergent and discriminant validity were calculated, as seen in Table 1. Further, Table 1 shows that both CR and CA coefficients of the measurement model were above 0.70 , which is the critical value, and thus the model was considered as a reliable model (Hair et al. 2014). Also, the coefficients of skewness and kurtosis of the variables in the model were in the range of -3 and +3 ; it follows that the data were normally distributed (Kline, 2014).

Table 2. Mean, Standard Deviation, $\sqrt{\mathrm{AVE}}, \mathrm{MSV}, \mathrm{ASV}$ and Pearson Correlation Coefficients.

\begin{tabular}{|l|l|l|l|l|l|l|l|l|l|l|}
\hline Dim. & Mean & SS & $\sqrt{\text { AVE }}$ & MSV & ASV & $\mathbf{2}$ & $\mathbf{3}$ & $\mathbf{4}$ & $\mathbf{5}$ & $\mathbf{6}$ \\
\hline 1.RES & 3.634 & 0.776 & 0.780 & 0.535 & 0.483 & $0.732^{* *}$ & $0.633^{* *}$ & $0.750^{* *}$ & $0.689^{* *}$ & $0.666^{* *}$ \\
\hline 2.OUT & 3.813 & 0.844 & 0.775 & 0.579 & 0.485 & 1 & $0.667^{* *}$ & $0.666^{* *}$ & $0.653^{* *}$ & $0.761^{* *}$ \\
\hline 3.PRO & 3.646 & 0.871 & 0.864 & 0.473 & 0.427 & & 1 & $0.688^{* *}$ & $0.628^{* *}$ & $0.673^{* *}$ \\
\hline 4.MAN & 3.612 & 0.787 & 0.825 & 0.605 & 0.477 & & & 1 & $0.778^{* *}$ & $0.753^{* *}$ \\
\hline 5.IMA & 3.525 & 0.796 & 0.752 & 0,562 & 0.487 & & & & 1 & $0.733^{* *}$ \\
\hline 6.SOR & 3.743 & 0.819 & 0.882 & 0,605 & 0.515 & & & & & 1 \\
\hline
\end{tabular}

Table 2 points out a positive and statistically significant $(\mathrm{p}<0.01)$ correlation between the dimensions of service quality and demonstrates that the averages of the dimensions were high. Table 3 presents the first-order multifactorial and second-order CFA fit indices of the measurement tool, which was already proved to be structurally valid and reliable.

Table 3. Confirmatory Factor Analysis Fit Indices

\begin{tabular}{|l|l|l|l|l|l|l|l|}
\hline $\begin{array}{l}\text { Measurement } \\
\text { Model }\end{array}$ & $\chi \mathbf{2}$ & sd & $\boldsymbol{\chi 2} / \mathbf{s d}$ & CFI & TLI & RMSEA & SRMR \\
\hline First Order CFA & 410 & 1092.824 & 2.665 & 0.927 & 0.917 & 0.073 & 0.034 \\
\hline Second Order CFA & 418 & 1117.500 & 2.673 & 0.925 & 9.917 & 0.073 & 0.037 \\
\hline
\end{tabular}

As seen in Table 3, the first-order and second-order CFA fit indices of the measurement model were within the acceptable range (Anderson and Gerbing, 1998; Hu and Bentler, 1999; Hair et al., 2014). 


\section{Conclusion and Suggestions}

With its each dimension explained by a set of descriptive factors, service quality in liner maritime transport consists of 31 variables and 6 dimensions, which are resources, outcomes, process, management, image and social responsibility (ROPMIS). This study, which seeks to identify the dimensions of the quality of services offered in maritime transport and to analyse the reliability and validity of these dimensions through structural equation modelling, drew on SPSS v22 and AMOS v22 Statistics to examine the data obtained from 316 employees working at 52 forwarder businesses through questionnaire. The validity of the measurement tool was confirmed through convergent and discriminant analyses and the reliability of the tool was tested based on combined reliability and Cronbach's Alpha coefficients; furthermore, the firstorder and second-order CFA fit indices of the measurement model were within the acceptable range. These findings indicate that this 6-dimensional scale for service quality in liner maritime transport may be used dimensionally or completely as a whole under the name of service quality in liner maritime transport. In other words, the scale for service quality in liner maritime transport can be utilized either as one-dimensional or as six-dimensional, depending on the purpose of researchers. This study has academic results as well as administrative results to offer. It confirms the composition of service quality in maritime transport created from the generic model developed by Thai (2008) and thus contributes to the existing literature. It also seeks to fill a gap in the literature, which results from insufficient studies in the field of service quality management in the maritime sector in general and in liner transportation in particular. As this study was performed with a single sector, this may serve as an obstace to generalization of the findings. For that reason, similar studies may be performed at intersectoral levels.

The primary limitation of this study is that the sample only consists of forwarder businesses that benefit from liner maritime transport services as carrier. It may be challenging to generalize the results obtained only from a single sector. Limiting the study to a single sector may lead to disregard issues related to the effects of sector differences. That is, the fact that the study sample did not include different organizations may serve as a lacking in the perception of the dimensions of service quality. This study suggests the use of the dimensions of service quality in liner transport not only in forwarders as customers but also import and export companies. Furthermore, in order to better understand service quality in liner maritime transport, future research need to be conducted to explore service quality not only in terms of the businesses (customers) receiving the service, but also in terms of those providing the service because the perceptions of those who provide and receive the service may differ. As for the demographic characteristics of the participants in this study, they not only work to offer forwarding services (i.e. organizing transportation), but also work in mostly shipping agencies, road transportation, air cargo transportation, project transformation as well as maritime transportation services such as brokering. In this regard, it is potential that the dimensions of service quality were assessed from the perspective of the people working in different sectors of maritime transport.

That is to say, it is possible that these dimensions may have been evaluated not only by the service provider, but also by the customers benefiting from transportation services. Similarly, future studies may consider other variables regarding the quality of services offered by liner businesses (customer satisfaction, behavioural intention) with the dimensions of service quality and determine which dimensions of service quality in liner transportation may have a mediator role between customer satisfaction and behavioural intention. 


\section{References}

Altan, Ş., \& Ediz, A. (2016). Türkiye'de yüksek hızlı tren(yht) için hizmet kalitesinin ölçümü, Gazi Üniversitesi İktisadi ve İdari Bilimler Fakültesi Dergisi, 18/3, 695-720.

Anderson, J., and Gerbing, D. (2017). Structural equation modeling in practice: A review and recommended two-step approach. Psychological Bulletin, 103(3).

Balci, G., I.B., Cetin and Tanyeri, M. ( 2018) Differentiation of container shipping services in Turkey. Transport Policy, 61, 26-35.

Bülbül, H., and Demirer, Ö. (2008). Hizmet kalitesi ölçüm modelleri servqual ve serperf' in karşılaştırmalı analizi, Selçuk Üniversitesi Sosyal Bilimler Enstitüsü Dergisi, 181198.

Chen, K.K., C.T Chang and Lai, C.S. (2009). Service quality gaps of business customers in the shipping industry, Transportation Research Part E: Logistics and Transportation Review, 45(1): 222-237.

Dennet't, C., E.M. Ineson, G.J. Stone and Colgate, M. ( 2000). Pre-bookable services in the chartered airline industry: increasing satisfaction through differentiation, The Service Industries Journal, 20(2), 82-94.

Ding, J.F., and Tsai, P.P. (2012). Evaluating quality improvement of service recovery for ocean freight forwarders in Taiwan, Information Technology Journal, 11(11):15791587.

Durvasula, S., S. Lysonski, and Mehta, S. (2002). Understanding the interfaces: How ocean freight shipping lines can maximize satisfaction, Industrial Marketing Management, 31(6), 491-504.

Durvasula, S., S. Lysonski, and Mehta, S. (1999). Testing the SERVQUAL scale in the business-to-business sector: The case of ocean freight shipping service, Journal of Services Marketing, 13 (2), 1999, 132 - 150.

Eleren, A. and Kılıç, B. (2007). Turizm sektöründe servqual analizi ile hizmet kalitesinin ölçülmesi ve bir termal otelde uygulama, Afyon Kocatepe Üniversitesi İktisadi ve İdari Bilimler Fakültesi Dergisi, 9 (1), 235 - 263.

Erenkol, A. D. (2005). Hizmet kalitesi ölçümünde kullanılan servqual modelinin zayıf olduğu ileri sürülen teorik ve uygulama yönlerine yönelik olarak yapılan değerlendirmeler, İstanbul Üniversitesi İktisat Fakültesi Maliye Araştırma Merkezi Konferanslart.

Fanam, Peter Dzakah and Leigh Ackerly (2019), Evaluating ocean carrier selection criteria: perspectives of Tasmanian shippers, Journal of Shipping and Trade, 4(5), 2-16.

Fornell, C., and D. F Larcker. (1981). Evaluating structural equation models with unobservable variables and measurement error. Journal of Marketing Research, 39-50.

Grönroos, C. (1984). A service quality model and 1ts marketing 1mplications. European Journal of Marketing, 18(4), 36-44.

Haralambides, H. E. (2007). Structure and operations in the layner shipping industry, Handbook Of Transport Modelling, Edi:2nd, Chapter: 40, Editors: K.J. Button and D.A. Hensher pp:607-621.

Hair, J. F., W. C. Black, B. J. Babin, and Anderson R. E. (2014). Multivariate data analysis. 7th ed. Upper Saddle River, New Jersey: Prentice Hall.

Ho, T.C., R.H. Chiu, C. C. Chung, and Hsuan, S. L. (2017). Key influence factors for ocean freight forwarders selectıng container shipping lines using the revised dematel approach, Journal of Marine Science and Technology, 25(3), 299-310.

Hu, L. T., and Bentler, P. M. (1999). Cut off criteria for fit indexes in covariance structure analysis: Conventional criteria versus new alternatives, Structural Equation Modeling: A Multidisciplinary Journal, 6(1), 1-55. 
Huang, S.T., E.Bulut \& Duru, O. (2015). Service quality assessment in layner shipping industry: an empirical study on Asian shipping case, Shipping and Transport Logistics, 7 (2), 221- I.

IMEAK Deniz Ticaret Odası (2019), Denizcilik Sektör Raporu, 1-329.

İkiz, H.E. (2010). Hizmet kalitesi modellerinin karşılaştırılması üzerine bir araştırma, Dokuz Eylül Üniversitesi Sosyal Bilimler Enstitüsü, Yayınlanmamış Doktora Tezi, s.1146.

Kannan,V., S.K. Bose and Kannan, N.G. (2011). An evaluation of ocean container carrier selection criteria: an Indian shipper's perspective, Management Research Review, 34(7), 754-772.

Kang, G.D and Y.D. Kim (2009). An analysis of the measurement of the shipping service quality, The Asian Journa of Shipping of Logistics, 25(1), 41-55.

Karsten, C.V. (2015). Competitive layner shipping network design, Technical University of Denmark DTU, Management Engineering Management Science, 1-281.

Kline, P. (2014). An easy guide to factor analysis. New York, NY: Routledge.

Kline, P. (2005). Principles and practice of structural equation modeling. The guilford press, New York, NY.

Parasuraman, A., Zeithaml, V.A. and Berry, L.L. (1988). SERVQUAL- A multipleitem scale for measuring consumer perceptions of service quality. Journal of Retailing. 64 (1): $12-40$.

Samija, S., I. Kolanovic \& Dundovic, C. (2015). Systematic approach to determining the factors of quality of maritime transport service, Poslovna Izvrsnost Zagreb, IX, 121-141.

Seth, N., S.G. Deshmukh and Vrat, P. (2005). Service quality models: a review, International Journal of Quality \& Reliability Management, 22 (9), 913-949.

Sürücü, E. and Sakar, G. D. (2018) . Sosyal medya aracılığıyla paydaş katılımının ölçülmesi: Türk lojistik hizmet sağlayan işletmeler üzerine bir inceleme, Dumlupınar Üniversitesi Sosyal Bilimler Dergisi, 58.

Thai, V.V. (2016), The impact of port service quality on customer satisfaction: The case of Singapore, Maritime Economics \& Logistics, 18 (4), 458-475.

Thai, V. V. (2008) Service quality in maritime transport: conceptual model and empirical evidence. Asia Pacific Journal of Marketing and Logistics, 20(4): 493-518.

Tuan, L. A., Vu H. T. and Nhan N L. ( 2018), Study of satisfaction of customers for the quality of sea transport services: case in tan cang shipping joint stock company danang branch, International Research Journal of Advanced Engineering and Science, 3(4), 220-224.

Tuna, Okan (2001), Dimensions of service quality in container transportation: An empirical investigation, developments in maritime transport and logistics in Turkey, ed. Mahmut Celal Barla, Osman Kamil Sag, Michael Roe and Richard Grey, London and Newyork, 26-34.

Yeo, G.T., V. V.,Thai and Roh, S.Y. (2015). An analysis of port service quality and customer satisfaction: the case of Korean container ports, The Asian Journal of Shipping and Logistics, 31(4), 437-447.

Yuen, K. F. and V.V. Thai, (2015), Service quality and customer satisfaction in layner shipping, International Journal of Quality and Sevice Sciences, 7(2/3),170-83.

Yüksel, M., and Önaçan, M. B. K. (2018). Algılanan hizmet kalitesinin müşteri memnuniyetine etkisi: Türkiye'de deniz yolcu taşımacılığında bir uygulama. Beykoz Akademi Dergisi, 6(2), 20-38. 
Zin,S. S., L.,Sarawut and Chaowarat, M. (2014). An empirical assessment of maritime logistics service quality in Myanmar, KMI International Journal of Maritime Affairs and Fisheries, Volume 6(2), 001-028.

APPENDIX 1: Dimensions and Criteria of ROPMIS Service Quality in Liner Transportation

\begin{tabular}{|c|c|c|}
\hline DIM. & CRITERIA & $\begin{array}{l}\text { PREVIOUS } \\
\text { STUDIES }\end{array}$ \\
\hline \multirow[t]{2}{*}{ RES } & $\begin{array}{l}\text { 1. The liner company uses the latest technology, equipment } \\
\text { and tools. } \\
2 \text {. Containers provided by the liner company are always in } \\
\text { good condition (clean, suitable for cargo and roadworthy). } \\
3 \text {. The liner company has a very strong technological } \\
\text { infrastructure for communication and information (its } \\
\text { booking system, website and online load tracking system are } \\
\text { functional). } \\
\text { 4. The liner company has a very strong and stable financial } \\
\text { position. }\end{array}$ & $\begin{array}{l}\text { Adapted } \\
\text { from Thai } \\
(2008)\end{array}$ \\
\hline & $\begin{array}{l}\text { 5. The liner company has human resources specialized in } \\
\text { operations related to maritime transportation. }\end{array}$ & $\begin{array}{l}\text { Zin }(2014) \text {, } \\
\text { Yuen \& Thai } \\
(2015)\end{array}$ \\
\hline \multirow[t]{5}{*}{ OUT } & $\begin{array}{l}\text { 6. The liner company can always deliver the cargo without } \\
\text { damage, loss and safely. } \\
\text { 7. The performance speed of the services offered by the liner } \\
\text { company (i.e. the voyages are carried out non-stop to the port } \\
\text { of arrival and the transit time is short) is satisfactory. } \\
\text { 8. The reliability of the service performance of the liner } \\
\text { company (i.e. the ability to comply with the departure and } \\
\text { arrival schedules announced in advance) is high. } \\
\text { 9. The liner company offers freight pricing (reasonable } \\
\text { freight offers) at more competitive rates than other } \\
\text { companies. }\end{array}$ & $\begin{array}{l}\text { Adapted } \\
\text { from Thai } \\
(2008)\end{array}$ \\
\hline & $\begin{array}{l}\text { 10. The liner company usually make discounts on local costs } \\
\text { (loading fee, terminal fee, temporary acceptance fee, etc.) (i.e. } \\
\text { it is willing to negotiate on freight rates). }\end{array}$ & $\begin{array}{l}\text { Ho et al., } \\
(2017) \\
\text { Fanam \& } \\
\text { Ackerly } \\
(2019)\end{array}$ \\
\hline & 11. The liner company is flexible in container free time. & $\begin{array}{l}\text { Kannan et } \\
\text { al., (2011) }\end{array}$ \\
\hline & $\begin{array}{l}\text { 12. The liner company has a high capacity to safely send the } \\
\text { cargo to the desired geographically-specific points. }\end{array}$ & $\begin{array}{l}\text { Kannan et } \\
\text { al., (2011) } \\
\text { Fanam \& } \\
\text { Ackerly } \\
(2019)\end{array}$ \\
\hline & $\begin{array}{l}\text { 13. The voyage frequency of the ships of the liner company is } \\
\text { satisfactory. }\end{array}$ & $\begin{array}{l}\text { Ding \& Tsai } \\
(2012) \\
\text { Yuen \& Thai } \\
(2015) \\
\text { Ho et al., } \\
(2017) \\
\text { Fanam \& } \\
\text { Ackerly } \\
(2019)\end{array}$ \\
\hline
\end{tabular}




\begin{tabular}{|c|c|c|}
\hline \multirow[t]{2}{*}{ PRO } & $\begin{array}{l}\text { 14. The liner company staff always provide consistent and } \\
\text { reliable service. } \\
\text { 15. The customer services of the liner company perform IT } \\
\text { and EDI applications effectively. } \\
\text { 16. The liner company provides fast and effective cargo } \\
\text { (container) tracking and informs its customers. } \\
\text { 17. The liner company staff are always willing to meet the } \\
\text { needs of customers and perform their services in a friendly, } \\
\text { courteous and helpful manner. } \\
\text { 18. In case of customer complaints, the liner company } \\
\text { quickly resolves the problem and offers fast solutions to the } \\
\text { constantly changing demands. }\end{array}$ & $\begin{array}{l}\text { Adapted } \\
\text { from Thai } \\
(2008)\end{array}$ \\
\hline & $\begin{array}{l}\text { 19. The liner company makes freight bookings correctly, } \\
\text { accurately and efficiently. }\end{array}$ & $\begin{array}{l}\text { Zin }(2014) \\
\text { Ho et al., } \\
(2017)\end{array}$ \\
\hline MAN & $\begin{array}{l}\text { 20. The liner company managers and staff are very effective } \\
\text { in their operations and management. } \\
21 \text {. The ability of the company managers to provide good } \\
\text { emergency management and support in emergencies (the } \\
\text { company comes up with measures for unexpected situations) } \\
\text { is high. } \\
\text { 22. The liner company efforts to continuously improve its } \\
\text { customer-oriented operation processes. } \\
\text { 23. The liner company regularly conducts surveys to receive } \\
\text { feedback on customer satisfaction. } \\
\text { 24. The liner company manages information technologies (IT, } \\
\text { EDI etc.) in accordance with its business objectives. }\end{array}$ & $\begin{array}{l}\text { Adapted } \\
\text { from Thai } \\
(2008)\end{array}$ \\
\hline \multirow[t]{3}{*}{ IMA } & $\begin{array}{l}\text { 25. The liner company has a good image and reputation in the } \\
\text { maritime community and is thus considered reliable. }\end{array}$ & Thai (2008) \\
\hline & $\begin{array}{l}\text { 26. The liner company has no past-experience of loss and } \\
\text { damage. }\end{array}$ & $\begin{array}{l}\text { Ding \& Tsai } \\
(2012) \\
\text { Zin et al., } \\
(2014)\end{array}$ \\
\hline & $\begin{array}{l}\text { 27. The liner company has a good reputation for its quality } \\
\text { and customer-oriented services. }\end{array}$ & $\begin{array}{l}\text { Fanam \& } \\
\text { Ackerly } \\
(2019) \\
\text { Ho et al., } \\
\text { (2017), } \\
\text { Zin et al., } \\
\text { (2014) }\end{array}$ \\
\hline \multirow[t]{2}{*}{ SOR } & $\begin{array}{l}\text { 28. The liner company performs its operations in an } \\
\text { environmentally friendly (clean and green environment) } \\
\text { manner (minimization of waste, conservation of resources, } \\
\text { etc.). } \\
\text { 29. The liner company acts socially responsible about human } \\
\text { safety. }\end{array}$ & $\begin{array}{l}\text { Adapted } \\
\text { from Thai } \\
(2008)\end{array}$ \\
\hline & $\begin{array}{l}\text { 30. The liner company pays attention to compliance with } \\
\text { internationally accepted standards of quality, environmental } \\
\text { management, occupational health and safety (ISO 14001, } \\
\text { OHSAS } 18001 \text { etc.). }\end{array}$ & $\begin{array}{l}\text { Kannan et } \\
\text { al., (2011) } \\
\text { Zin et al., } \\
(2014)\end{array}$ \\
\hline
\end{tabular}




\begin{tabular}{|l|l|l|}
\hline $\begin{array}{l}\text { 31. The liner company uses clean and low-sulfur fuels on its } \\
\text { ships (to prevent ship-sourced pollution). }\end{array}$ & $\begin{array}{l}\text { Yuen \& Thai } \\
\text { (2015) } \\
\text { Zin et al., } \\
(2014)\end{array}$ \\
& \\
\hline
\end{tabular}

EK 1: Layner Tașımacılığı ROPMIS Hizmet Kalitesi ile ilgili Boyutlar ve Kriterler

\begin{tabular}{|c|c|c|}
\hline BOY. & KRİTERLER & $\begin{array}{l}\text { ÖNCEKI } \\
\text { ÇALIŞMALAR }\end{array}$ \\
\hline \multirow[t]{2}{*}{ KAY. } & $\begin{array}{l}\text { 1. Layner firması, en son teknoloji, ekipman ve } \\
\text { araçlar kullanır. } \\
\text { 2. Layner firmasının sağladığı konteynerlerin } \\
\text { durumları her zaman iyi (temiz, yüke ve yola } \\
\text { elverişli) durumdadır. } \\
\text { 3. Layner firmasının iletişim ve bilgilendirmeyi } \\
\text { gerçekleştirecek teknolojik altyapısı oldukça } \\
\text { güçlüdür (booking sistemi, internet web sitesi ve } \\
\text { online yük takip sistemi işlevsel). } \\
\text { 4. Layner firması oldukça güçlü ve istikrarlı } \\
\text { finansal pozisyona sahiptir. }\end{array}$ & $\begin{array}{l}\text { Thai'den (2008) } \\
\text { uyarlanmıştır }\end{array}$ \\
\hline & $\begin{array}{l}\text { 5. Layner firması deniz taşımacılığı ile ilgili } \\
\text { işlemler hususunda uzman insan kaynaklarına } \\
\text { sahiptir. }\end{array}$ & $\begin{array}{l}\text { Zin }(2014) \text {, } \\
\text { Yuen \& Thai (2015) }\end{array}$ \\
\hline \multirow[t]{5}{*}{ ÇIK. } & $\begin{array}{l}\text { 6. Layner firması yüklerin daima hasarsız, kayıpsız } \\
\text { ve güvenli bir şekilde teslim etme becerisine } \\
\text { sahiptir. } \\
\text { 7. Layner firması hizmetlerinin performans hızı } \\
\text { (gemi seferlerinin varma limanına aktarmasız } \\
\text { olarak gerçekleştirilmesi ve transitte geçen sürenin } \\
\text { kısa olması) memnuniyet verici düzeydedir. } \\
\text { 8. Layner firmasının hizmet performansının } \\
\text { güvenilirliği (önceden ilan etmiş olduğu gemi } \\
\text { kalkış ve varış sefer programlarına uyma yeteneği) } \\
\text { yüksektir. } \\
\text { 9. Layner firmasının diğer firmalara göre daha } \\
\text { rekabetçi oranlarda navlun fiyatlandırması (uygun } \\
\text { navlun teklifi) yapmaktadır. }\end{array}$ & $\begin{array}{l}\text { Thai'den }(2008) \\
\text { uyarlanmıştır }\end{array}$ \\
\hline & $\begin{array}{l}\text { 10. Layner firmasının genel olarak lokal } \\
\text { masraflarda (yükleme ücreti, terminal ücreti, geçici } \\
\text { kabul ücreti v.b) indirim sağlamaktadır (navlun } \\
\text { oranlarında pazarlık etmeye istekli). }\end{array}$ & $\begin{array}{l}\text { Ho vd., (2017) } \\
\text { Fanam \& Ackerly (2019) }\end{array}$ \\
\hline & $\begin{array}{l}\text { 11. Layner Firması, konteyner serbest sürelerinde } \\
\text { (free time) esneklik sağlar. }\end{array}$ & Kannan vd., (2011) \\
\hline & $\begin{array}{l}\text { 12. Layner Firmasının, istenilen coğrafik olarak } \\
\text { spesifik noktalara güvenilir bir şekilde yük } \\
\text { gönderebilme kapasitesi yüksektir. }\end{array}$ & $\begin{array}{l}\text { Kannan vd., (2011) } \\
\text { Fanam \&Ackerly (2019) }\end{array}$ \\
\hline & $\begin{array}{l}\text { 13. Layner Firması gemilerinin sefer sıklığ } 1 \\
\text { memnuniyet verici düzeydedir. }\end{array}$ & $\begin{array}{l}\text { Ding \& Tsai (2012) } \\
\text { Yuen \& Thai (2015) } \\
\text { Ho vd., } 2017\end{array}$ \\
\hline
\end{tabular}




\begin{tabular}{|c|c|c|}
\hline & & $\begin{array}{l}\text { Fanam and Ackerly } \\
(2019)\end{array}$ \\
\hline \multirow[t]{2}{*}{ SÜR. } & $\begin{array}{l}\text { 14. Layner firması personeli her zaman tutarlı ve } \\
\text { güvenilir bir şekilde hizmet sunmaktadır } \\
\text { 15. Layner firmasının müşteri hizmetlerinde IT ve } \\
\text { EDI uygulamalarını etkin bir şekilde } \\
\text { gerçekleştirirler. } \\
\text { 16. Layner firması hızlı ve etkin yük (konteyner) } \\
\text { takibi yapıp, müşterisini bilgilendirmektedir. } \\
\text { 17. Layner firması personeli daima müşterilerin } \\
\text { gereksinimlerini karşılamaya istekli ve samimi, } \\
\text { nazik ve yardımsever bir şekilde hizmetlerini } \\
\text { gerçekleştirirler. } \\
\text { 18. Layner firması, müşteri şikâyetleri olursa, hızlı } \\
\text { bir şekilde çözüme kavuşturması ve devamlı } \\
\text { değişen taleplerine hızlı çözümler getirirler }\end{array}$ & $\begin{array}{l}\text { Thai'den (2008) } \\
\text { uyarlanmıştır }\end{array}$ \\
\hline & $\begin{array}{l}\text { 19. Layner firması, yük rezervasyonlarını (booking) } \\
\text { doğru, hatasız ve etkin bir șekilde gerçekleștirirler. }\end{array}$ & $\begin{array}{l}\text { Zin }(2014) \\
\text { Ho vd.,2017 }\end{array}$ \\
\hline YÖN. & $\begin{array}{l}\text { 20. Layner firma yöneticinin ve personelinin } \\
\text { operasyon ve yönetimlerinde oldukça etkindirler. } \\
\text { 21. Firma yöneticilerinin acil durumlarda, iyi bir } \\
\text { acil durum yönetim ve desteği sağlayabilme } \\
\text { yeteneği (firmanın beklenmedik durumlar için } \\
\text { önlem geliştirmesi) yüksektir. } \\
\text { 22. Layner firmasının müşteri odaklı operasyon } \\
\text { süreçlerinde sürekli iyileştirme çabaları vardır. } \\
\text { 23. Layner firmasının müşteri memnuniyeti ile ilgili } \\
\text { geri bildirimler almak için düzenli olarak anket } \\
\text { uygularlar. } \\
\text { 24. Layner firması bilgi teknolojilerini (IT, EDI vb) } \\
\text { iş hedeflerine uygun şekilde yönetirler. }\end{array}$ & $\begin{array}{l}\text { Thai'den (2008) } \\
\text { uyarlanmıştır }\end{array}$ \\
\hline \multirow[t]{3}{*}{ İMAJ } & $\begin{array}{l}\text { 25. Layner firmasının denizcilik camiasında } \\
\text { güvenilirlik yönünden iyi bir imajı ve itibarları } \\
\text { vardır. }\end{array}$ & Thai (2008) \\
\hline & $\begin{array}{l}\text { 26. Layner firmasının geçmişinde kayıp ve hasar } \\
\text { deneyimi yoktur. }\end{array}$ & $\begin{array}{l}\text { Ding \&Tsai (2012) } \\
\text { Zin vd., (2014), }\end{array}$ \\
\hline & $\begin{array}{l}\text { 27. Layner firması kalite ve müşteri odaklı } \\
\text { hizmetler konusunda iyi bir üne sahiptir. }\end{array}$ & $\begin{array}{l}\text { Fanam \&Ackerly (2019) } \\
\text { Ho vd., (2017), } \\
\text { Zin vd., (2014) }\end{array}$ \\
\hline \multirow[t]{3}{*}{ SOS. } & $\begin{array}{l}\text { 28. Layner Firması operasyonlarını çevreye duyarlı } \\
\text { (temiz ve yeşil çevre) bir şekilde gerçekleştirmesi } \\
\text { (atıkların minimizasyonu, kaynakların korunması } \\
\text { vb). } \\
\text { 29.Layner firması insan güvenliği ile ilgili sosyal } \\
\text { olarak sorumlu davranışlarda bulunması. }\end{array}$ & $\begin{array}{l}\text { Thai'den (2008) } \\
\text { uyarlanmıştır }\end{array}$ \\
\hline & $\begin{array}{l}\text { 30. Layner firması, uluslararası kabul görmüş } \\
\text { kalite, çevre yönetimi, iş sağlığı ve güvenliği (ISO } \\
\text { 14001, OHSAS } 18001 \text { v.b ) ile ilgili standartlara } \\
\text { uyma konusunda oldukça hassastır. }\end{array}$ & $\begin{array}{l}\text { Kannan vd., (2011) } \\
\text { Zin vd., (2014) }\end{array}$ \\
\hline & $\begin{array}{l}\text { 31. Layner firması gemilerinde temiz ve düşük } \\
\text { kükürtlü yakıtları kullanır (gemi kaynaklı kirliliğin } \\
\text { önlenmesi için). }\end{array}$ & $\begin{array}{l}\text { Yuen\& Thai (2015) } \\
\text { Zin vd., (2014) }\end{array}$ \\
\hline
\end{tabular}

